\title{
APPLICATION OF TALKING CHIPS LEARNING MODEL TO IMPROVE ACTIVITIES AND RESULTS OF CHEMICAL LEARNING IN MAN 13 JAKARTA
}

\author{
Diyah Fitri Rhochani" ${ }^{* 1}$, Kurroti A'yun ${ }^{2}$ \\ ${ }^{1}$ Madrasah Aliyah Negeri 13 Jakarta \\ ${ }^{2}$ Sekolah Tinggi Ilmu Tarbiyah al-Urwatul Wutsqo Jombang \\ *Corresponding author: rhochani@yahoo.com
}

\begin{abstract}
This study aims to determine the increase in activity and learning outcomes of Chemistry in the material of chemical bonds by applying the Talking Chips learning model. The subject of this study were students of $10^{\text {th }}$ grade in MIA-2 class of MAN 13 Jakarta with a total of 31 students in the odd semester of 2017/2018 school year. This study uses classroom action research (CAR) method which consists of two cycles, each cycle consists of four stages. Data collection techniques used are tests of student learning outcomes in each cycle as well as observation sheets of student and teacher activities. The results showed that the completeness of learning criteria had been achieved by increasing the average student learning outcomes from cycle I by 68\% to $97 \%$ and in cycle II it had increased by 29\%. Increases also occur in student learning activities with an increase in value of each from cycle I by $61 \%$ to $85 \%$ in cycle II. Based on the results of these studies, it can be said that by using the Talking Chips learning model, student activities and learning outcomes can be improved.
\end{abstract}

Keywords: talking chips model, activities, learning outcomes

\section{PENDAHULUAN}

Pendidikan pada dasarnya merupakan proses untuk membantu manusia dalam mengembangkan diri sehingga mampu menghadapi segala perubahan dan permasalahan dengan sikap terbuka melalui pendekatan-pendekatan yang kreatif tanpa menghilangkan identitas diri. Pendidikan sering kali disejajarkan dengan pembelajaran, sebab kedua istilah ini sangat popular digunakan di lembaga-lembaga pendidikan [1]. Namun, sesungguhnya kedua istilah ini memiliki perbedaan masing-masing.

Perbedaan antara pendidikan dan pembelajaran dapat dilihat dari makna dari masing-masing kata. Pendidikan bermakna usaha sadar untuk mendewasakan peserta didik dengan mentransfer nilai-nilai (value), sedangkan pembelajaran bermakna usaha sadar untuk mendewasakan peserta didik dengan mentransfer pengetahuan (kognitif). Makna pendidikan dan pembelajaran ini disarikan dari isi Undang-Undang tentang Sistem Pendidikan Nasional dan UndangUndang tentang Pendidikan Tinggi [2, 3].
Berdasarkan Undang-Undang tentang Sistem Pendidikan Nasional tersebut, pendidikan didefinisikan sebagai usaha sadar dan terencana untuk mewujudkan suasana belajar dan prosespembelajaran agar peserta didik secara aktif mengembangkan potensi dirinya untuk memiliki kekuatanspiritual keagamaan, pengendalian diri, kepribadian, kecerdasan, akhlak mulia, serta keterampilan yangdiperlukan dirinya, masyarakat, bangsa, dan negara. Pembelajaran didefinisikan sebagai proses interaksi peserta didik dengan pendidik dan sumber belajar pada suatulingkungan belajar $[4,5]$.

Peserta didik merupakan sumber utama dan terpenting dalam proses pembelajaran, terutama pembelajaran formal [6]. Peserta didik dapat belajar tanpa pendidik, namun sebaliknya, pendidik tidak dapat mengajar tanpa adanya peserta didik. Oleh karena itu kehadiran peserta didik menjadi hal yang cukup penting dalam proses pembelajaran.

Pendapat tentang pentingnya kehadiran peserta didik dalam proses pembelajaran sejalan dengan pengertian pembelajaran yang dijelaskan oleh Pemerintah RI dalam Undang-

Vol. 2, No. 1, June 2018 
Undang [2,3] dan Peraturan Pemerintah [7]. Proses pembelajaran hendaknya diselenggarakan secara interaktif, inspiratif, menyenangkan, menantang, memotivasi peserta didik untuk berpartisipasi aktif, serta memberikan ruang yang cukup bagi prakarsa, kreativitas, dan kemandirian sesuai dengan bakat, minat, dan perkembangan fisik serta psikologis peserta didik [7, 8]. Peserta didik yang menjadi objek dalam peraturan ini. Oleh karena itu, diperlukan solusi terbaik untuk peserta didik agar dapat mengikuti proses pembelajaran dengan baik.

Proses pembelajaran dikatakan terlaksana berhasil apabila peserta didik terlibat aktif dan hasil belajar peserta didik sesuai dengan kriteria ketuntasan minimum (KKM) yang telah ditentukan oleh pendidik. Pendidik sebagai subjek dalam proses pembelajaran memiliki hak untuk menentukan keterlaksanaan dan keberhasilan suatu proses pembelajaran. Oleh karena itu, pendidik ikut menjadi penentu peningkatan aktivitas dan hasil belajar peserta didik.

Terdapat beberapa hal yang dapat menyebabkan aktivitaspeserta didik rendah dalam proses pembelajaran, di antaranya: (a) peserta didik merasa bosan atau kurangnyatantangan, (b) peserta didik merupakan subjek dari kondisi yangtidak menantang, (c) peserta didik merasa frustasi karena dalam kondisi yang tidakmenyenangkan, misalnya pemberian informasi yang tidak dimengerti oleh peserta didik, dan(d) tidak adanya penghargaan oleh pendidik terhadap peserta didik [9].Untuk meningkatkan hasil belajar peserta didik terdapat beberapa hal yang harus diperhatikan, di antaranya: (a) motivasi peserta didik belajar yang masih rendah,(b) persepsi peserta didik, (c) media pembelajaran yang terbatas, (d)sarana dan pra sarana yang tidak memenuhi syarat untuk melaksanakan proses pembelajaran, (e) latar belakang pendidikan peserta didikyang berbeda-beda, dan (f) pendidik belum menemukan cara yang tepat dalam membangunpemahaman awal peserta didik dalam mempelajari materi yang akan diajarkan [10].

Mengacu pada faktor-faktor yang mempengaruhi aktivitas dan hasil belajar di atas, peneliti mengambil benang merah bahwa proses pembelajaran yang dilakukan oleh pendidik di dalam kelas sangat berpengaruh terhadap peningkatan aktivitas dan hasil belajar peserta didik. Maka dari itu seorang pendidik harus berusaha mengoptimalkan kondisi belajar mengajar yang efektif terutama pada pelajaran kimia, sebab pelajaran kimia merupakan pelajaran yang dianggap sulit bagi siswa [11].

Pernyataan tersebut menjadi suatu alasan adanya fakta bahwa nilai kimia peserta didik kelas X MIA-2 MAN 13 Jakarta sebagian besar belum memenuhi kriteria ketuntasan minimal (KKM). Nilai rata-rata kimia pada ulangan harian hanya 65 sedangkan ketuntasan siswa yang mendapatkan nilai $\geq \mathrm{KKM}$ (Kriteria Ketuntasan Minimal) sebesar 75 hanya $35 \%$. Oleh karena itu, beberapa di antara peserta didik harus mengikuti perbaikan agar dapat mencapai nilai ketuntasan minimal. Beberapa siswa kelas $\mathrm{X}$ mengalami kesulitan dalam memahami pelajaran kimia khususnya materi ikatan kimia di antaranya konsep ikatan ion, ikatan kovalen, ikatan kovalen koordinasi, ikatan logam dan gaya antar partikel. Selain itu suasana belajar yang cenderung pasif menjadikan siswa kurang termotivasi dan gairah belajarnya relatif menurun. Metode maupun model pembelajaran yang diterapkan selama ini belum mampu meningkatkan kreatifitas dan hasil belajar siswa.

Berdasarkan hasil wawancara mendalam pada peserta didik, diketahui bahwa pelajaran kimia menjadi momok yang menakutkan karena adanyapandangan yang salah tentang kimia itu sendiri. Selama ini para siswamenganggap konsep-konsep yang ada dalam pelajaran kimia sebagai konsepkonsepabstrak yang sulit diaplikasikan ke dalam kehidupan nyata. Kesulitan dalam mempelajari kimia sebenarnya berawal dari kurangnyapemahaman dan penguasaan konsep dasar dalam kimia. Untuk menanamkanpemahaman akan konsep-konsep tersebut dan agar pembelajaran lebih optimal maka diperlukan suatu media pembelajaran yang dibarengi denganmodel pembelajaran yang dapat mengeksplorasi kemampuan siswa secara efektif dan selektif sesuai dengan konsep yang diajarkan sehingga siswa termotivasi untuk berperan aktif dalam proses pembelajaran.Oleh karena itu, guru dituntut 
untuk mempunyaikreativitas yang tinggi dalam menggunakan model pembelajaran untukmenunjang tercapainya proses belajar mengajar.

Peneliti sebagai guru tergugah untuk menggunakan salah satu model pembelajaran yang membuat siswa lebih aktif, yaitu model pembelajaran kooperatif Talking Chips. Model pembelajaran Talking Chips adalah salah satu model pembelajaran kooperatif yang masingmasing anggota kelompoknya mendapat kesempatan yang sama untuk memberikankontribusi mereka,mendengarkan pandangan, serta pemikiran anggota kelompok lain [12].Oleh sebab itu, peneliti ingin melakukan penelitian tindakan kelas dengan judul "Penerapan Model Pembelajaran Talking Chips untuk Meningkatkan Aktivitas dan Hasil Belajar Materi Ikatan Kimia pada Siswa Kelas X MIA -2 Semester Gasal MAN 13 Jakarta Tahun Pelajaran 2017/2018”.

\section{METODE}

Metode penelitian yang digunakan dalam penelitian ini adalah metode penelitian tindakan, khususnya metode penelitian tindakan kelas (PTK). Penelitian tindakan (action research) termasuk dalam ruang lingkup penelitian terapan(applied research) yang menggabungkan antara pengetahuan, penelitian dan tindakan [13].

Model PTK yang digunakan pada penelitian ini adalah model PTK Kemmis \& Taggart yang dijelaskan oleh keterangan penelitian terdahulu [13]. Model PTK Kemmis \&Taggart ini menggunakan empat tahap, yaitu (1) tahap perencanaantindakan(actionplan), (2) tahap tindakan (action), (3)tahap pengamatan (observation), dan (4) refleksi(reflection). Keempat rangkaian kegiatan dilakukan dalam siklus berulang yang merupakan ciri penelitian tindakan; total dua siklus yang digunakan. Ilustrasi siklus PTK pada penelitian ini disajikan pada Gambar 1 .

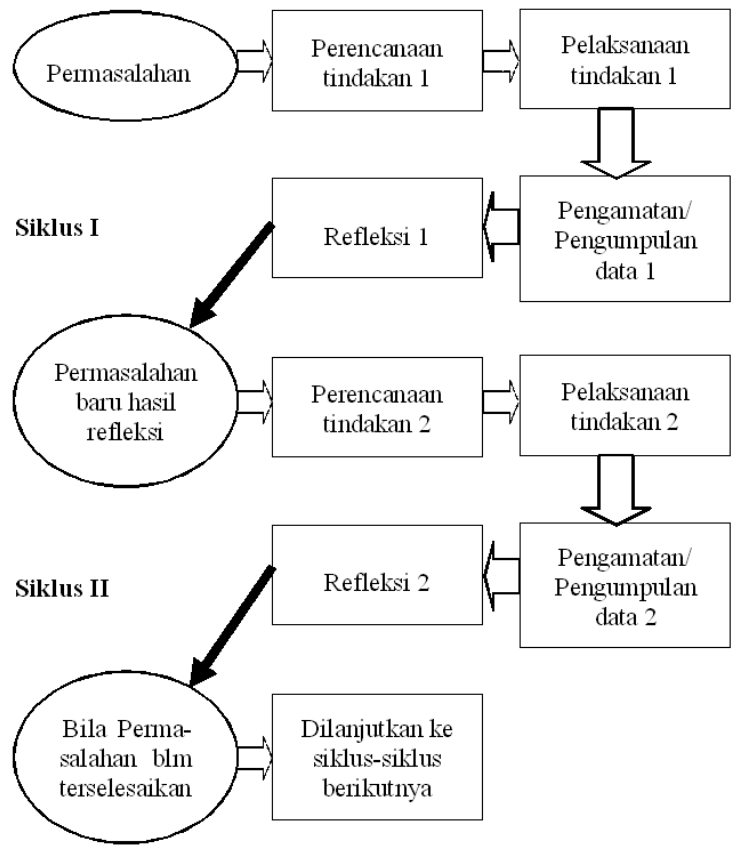

Gambar 1 Ilustrasi Rangkaian Kegiatan PTK

\section{Subjek, Waktu, dan Lokasi Penelitian}

Subjek penelitian ini adalah siswa kelas $X$ MIA 2 sebanyak 31 siswa yang terdiri atas putra 11 orang dan putri 20 orang. Jumlah tenaga pendidik di MAN 13 Jakarta sebanyak 54 orang sedangkan tenaga kependidikan sebanyak 32 orang. Peneliti sendiri merupakan pendidik mata pelajaran kimia di kelas $\mathrm{X}$ dan XII. Materi yang disampaikan pada Penelitian Tindakan Kelas (PTK) ini adalah ikatan kimia. Penelitian Tindakan Kelas (PTK) ini dilakukan selama 6 bulan dimulai dari praPTK hingga seminar PTK dan pelaporan hasil PTK, bulan Juli sampai dengan Desember tahun 2017 semester gasal tahun pelajaran 2017/2018.

\section{Teknik Pengumpulan Datadan Analisis Data}

Data tentang aktivitas peserta didik dan pendidik diamati oleh observer menggunakan lembar observasi sesuai ketentuan dalam buku [14]. Data tentang hasil belajar peserta didik diperoleh melalui pemberian tes secara tertulis di setiap pertemuan yang mengacu pada ahli [15].

Data yang diperoleh dari kegiatan pembelajaran dianalisis dengan menggunakan Penafsiran Acuan Patokan (PAP). Penggunaan PAP pada penelitian ini didasarkan pada keterangan [16], dengan ketentuan yang dapat dilihat pada Tabel 1 . 
Tabel 1 Penafsiran Acuan Patokan (PAP) pada Penelitian ini

\begin{tabular}{cc}
\hline Tingkat Penguasaan & Predikat \\
\hline $85-100 \%$ & Sangat baik \\
$75-84 \%$ & Baik \\
$70-74 \%$ & Cukup \\
$50-69 \%$ & Kurang \\
$10-49 \%$ & Kurang sekali \\
\hline
\end{tabular}

Penafsirandiatasdigunakanuntukmenetapkanti ngkataktivitasdantingkat penguasaan masingmasing siswa pada materi yang diajarkan. Adapun rumus yang digunakan dalam menetapkan persentase aktivitas dan hasil belajaradalah:

$\%$ Aktivitas Bela jar $=\frac{\sum \text { Frek. Aktivitas }}{\sum \text { Total Frek. Aktivitas }} \times 100 \%$ $\%$ Hasil Belajar $=\frac{\sum \text { Frek. Hasil Belajar }}{\sum \text { Total Frek. Hasil Belajar }} \times 100 \%$

Keterangan:

Frek $=$ Frekuensi

Berdasarkan dua rumus tersebut, peneliti menentukan indikator keberhasilan penelitian, yaitu: (1) penelitian akan dinyatakan berhasil apabila aktivitas belajar siswa dalam kelompok mencapai 75\%, (2) terjadi peningkatan hasil belajar siswa sekurangkurangnya $\quad 75 \%$ dari jumlahsiswa,memperolehnilai>75(nilaiKKM)a taudengankatalain persentase ketuntasan klasikal sekurang-kurangnya $75 \%$.

\section{Instrumen Penelitian}

Instrumen penelitian yang digunakan peneliti pada penelitian ini ada dua, yaitu:

1. Lembar observasi pendidikyang disusun dan digunakan dalam mengevaluasipersiapanpembelajarandank egiatanbelajarmengajar dikelas. Sedangkan lembar observasi aktivitas peserta didik digunakan untuk mengamati aktivitas peserta didik selama prosespembelajaran.

2 Tes hasil belajarpeserta didik yangdisusundandiberikansaatberakhirnyap rosesbelajar mengajar untuk mengukur kriteria keberhasilan dalam tindakan kelas

\section{HASIL DAN PEMBAHASAN}

\section{Hasil Penelitian}

Hasil penelitian ini terbagi menjadi empat bagian, yaitu: (1) hasil observasi kegiatan pendidik (guru), (2) hasil observasi aktivitas peserta didik (siswa), (3) hasil belajar siswa, dan (4) hasil refleksi pada siklus I dan II. Masing-masing hasil penelitian dari poin (1) sampai (3) ini digambarkan secara rinngkas pada Gambar 2 sampai 4, sedangkan poin (4) dijelaskan tersendiri mmenggunakan pernyataan verbal di bawah Gambar 4.

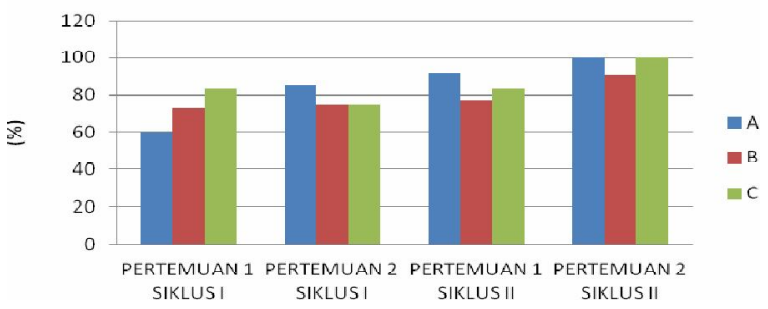

\section{Gambar 2 Hasil Observasi Kegiatan Guru}

Keterangan:

$\mathrm{A}=$ Perangkat kegiatan belajarmengajar

$\mathrm{B}=$ Pelaksanaan pembelajaran di kelas

$\mathrm{C}=$ Suasanabelajar

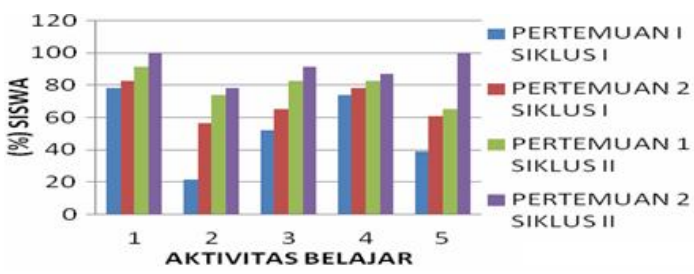

Gambar 3 Hasil Observasi Aktivitas Siswa

Keterangan:

$1=$ Bekerja sama dalam kelompok

$2=$ Bertanya kepada guru

$3=$ Aktif dalam diskusi

$4=$ Tanggung jawab terhadap tugas kelompok

$5=$ Ketepatan mengumpulkan tugas kelompok

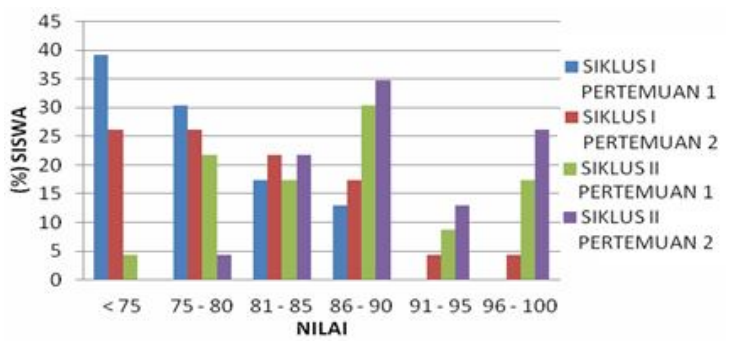

Gambar 4 Hasil Belajar Siswa 
Keterangan:

$1=$ Bekerja sama dalam kelompok

$2=$ Bertanya kepada guru

$3=$ Aktif dalam diskusi

$4=$ Tanggung jawab terhadap tugas kelompok

$5=$ Ketepatan mengumpulkan tugas kelompok

Berdasarkan hasil yang diperlihatkan pada Gambar 2 sampai 4 khususnya pada siklus I, peneliti menentukan beberapahalperludiperbaikidalampelaksanaans iklusII, di antaranya: (1) waktu pembelajaran pada siklus I masih belum efektif dan efisien, sehingga pada siklus II waktu pembelajaran harus diatur sebaikmungkin, (2) siswa sulit beradaptasi dengan ruang belajar yang tidak biasa, sehingga pembelajaran sebaiknya dilakukan di ruang kelasbiasa, (3) siswa masih kurang antusias dalam berdiskusi kelompok, sehingga perlu dimotivasi agar siswa semakin antusias dan bersemangat untuk menyusun power point, (4) siswa harus lebih sering dimotivasi untuk menggunakan kartunya (Talking Chips) ketika ingin bertanya, menjawab atau mengeluarkan pendapat sehingga semua siswa memiliki kesempatan yang sama untukaktif. Berdasarkan hasil yang diperlihatkan pada Gambar 2 sampai 4 khususnya pada siklus II, peneliti telah mendapatkan temuan adanya perbaikan, di antaranya: (1) siswa sudah memahami pembelajaranmenggunakan Talking Chips sehingga proses pembelajaran berhasil memotivasi siswa, hal ini terlihat siswa sangat aktif selama prosespembelajaran, (2) proses pembelajaran dilakukan diruang kelas biasa sehingga siswa merasanyaman,

managemen waktu dalam pengelolaan pembelajaran dengan menggunakan model Talking Chips telah berjalan sesuai dengan perencanaanpembelajaran, (4) hasil belajar siswa yang telah memenuhi kriteria ketuntasan minimal (KKM) 75 sebesar97\%.

\section{Pembahasan}

\section{Observasi Guru}

Pelaksanaan observasi kegiatan guru dilakukan dengan menggunakan lembar pengamatan yang terdiri dari tiga indikator yaitu: (A) persiapan kegiatan pembelajaran,

(B) pelaksanaan pembelajarandi kelas dan

(C) suasanabelajar. Pada indikator (A) persiapan kegiatan pembelajaran pertemuan 1 siklus I sebesar $60 \%$ hal ini disebabkan guru belum menyiapkan perangkat pembelajaran secara maksimal. Terjadi peningkatan di pertemuan 2 siklus I sebesar $85 \%$, pertemuan 1 siklus II sebesar $92 \%$ dan pertemuan 2 siklus II sebesar $100 \%$. Hal ini disebabkan guru telah mempersiapkan perangkat pembelajaran dengan baik seperti silabus, RPP, buku penunjang, lembar observasi guru dan siswa, dan lembar evaluasi.

Padaindikator(B)pelaksanaanpembelajar andikelas,pertemuan 1 siklus I sebesar $73 \%$ hal ini disebabkan guru belum maksimal dalam

pengelolaanwaktu.Terjadipeningkatandiperte muan2siklusIsebesar $75 \%$, pertemuan 1 siklus II sebesar 77\%, pertemuan 2 siklus II sebesar 90\%. Dikarenakan pada proses pembelajaran guru sudah mengelola waktu denganbaik. Pada indikator (C) suasana belajar, pertemuan 1 siklus I sebesar $83 \%$. Terjadi penurunan pada pertemuan 2 siklus I sebesar $75 \%$ hal ini disebabkan siswa sudah merasa lelah, ada dua ulangan di hari tersebut. Sehingga suasana belajar menjadi pasif, dan proses pembelajaran berpusat pada guru. Terjadi peningkatan kembali pada pertemuan 1 siklus II sebesar $83 \%$ dan pertemuan 2 siklus II sebesar $100 \%$ dikarenakan guru meningkatkan pengelolaan terhadap proses pembelajaran dalam hal memotivasi siswa.

Kegiatan memotivasi siswa dapat dilakukan guru dengan memilihdan mengkombinasikan beberapa model pembelajaran yang tepat agar dapatmenciptakan lingkungan belajar yang kondusif, dalam artian dapat memicu keingintahuan siswa agar terlibat aktif dalam kegiatan belajar mengajar [10, 17].Keterlibatan siswa secara aktif dalam proses belajar mengajar memberi peluangbesar terhadap pencapaian tujuan pembelajaran. Oleh karena itu, motivasi dalam pembelajaran sangat dibutuhkan untuk terjadinya percepatan dalam mencapai tujuan pembelajaran. Hal ini dapat dilihat pada suasana pembelajaran pada siklus II lebih terkendali jika dibandingkan dengan siklus I. Secara umum tujuan pembelajaran yang 
direncanakan bisa tercapai dan pembelajaran tidak mengalami hambatan yang berarti.

\section{Aktivitas Siswa}

Siswa yang bergantung pada temannya terlihat memiliki nilai yang tidak dapat mencapai kriteria ketuntasan yaitu $\geq 75$. Pada pertemuan pertama siklus I, hanya dua kelompok yang berhasil menyusun power point. Selain itu tidak cukup waktu untuk melaksanakan presentasi dengan power point, sehingga presentasi dilaksanakan pada pertemuan kedua siklus I. Hal ini dikarenakan guru kurang efektif dalam pengelolaan waktu pembelajaran di setiap tahapannya. Siswa pun belum terbiasa menggunakan kartunya ketika bertanya pada guru, menjawab ataupun memberikan pendapat saat bekerja dalam kelompok.

Pada pertemuan kedua siklus I, pada 7 menit pertama suasana belajar kurang kondusif karena pembelajaran tidak dilakukan di ruang kelas biasa. Namun setelah siswa duduk secara berkelompok pembelajaran berjalan lebih lancar karena siswa sudah memahami tahapan pembelajaran. Ada tiga kelompok yang berhasil menyusun powerpoint dan mempresentasikannya. Namun masih terlihat siswa yang kurang aktif berdiskusi saat presentasi kelompok. Pada siklus II,aktivitas siswa dalam kerja kelompok terjadi peningkatan sehingga semua kelompok berhasil menyusun powerpoint.

Pada pengamatan aktivitas kelompok ada beberapa hal yang diukurya itu bekerjasama dalam kelompok, bertanya kepada guru, aktif dalam diskusi, tanggung jawab terhadap tugas kelompok, dan ketepatan mengumpulkan tugas kelompok. Penilaian dilakukan setiap pertemuan dengan tujuan melihat perkembangan aktivitas siswa dalam kelompok. Pada siklus I rata-rata aktivitas siswa dalam kelompok sebesar $61 \%$ termasuk dalam kategori kurang aktif, terjadi peningkatan sebesar $24 \%$ pada siklus II menjadi kategori sangat aktif yaitu sebesar $85 \%$, yang dapat diamati pada Gambar 3 .

Berdasarkan Gambar 3 dapat dikatakan bahwa aktivitas siswa dalam kelompok masuk dalam kategori sangat aktif. Kategori aktivitas siswa ini didapatkan dari ketentuan mengenai kriteria aktivitas siswa. Untuk memberikan makna pada skor yang ada, dibuat bentuk kategori menurut tingkatan yang ada, kategori terdiri dari lima kategori yaitu sangat tinggi, tinggi, sedang, rendah dan sangat rendah $[16,18]$.

Tabel 2 Kriteria Aktivitas Siswa

\begin{tabular}{cc}
\hline Tingkat Aktivitas & Predikat \\
\hline $\mathbf{8 5}-\mathbf{1 0 0 \%}$ & Sangat aktif \\
$\mathbf{7 5 - \mathbf { 8 4 \% }}$ & Aktif \\
$\mathbf{7 0 - 7 4 \%}$ & Cukup \\
$\mathbf{5 0 - 6 9 \%}$ & Kurang \\
$\mathbf{1 0 - 4 9 \%}$ & Kurang sekali \\
\hline
\end{tabular}

\section{Hasil Belajar}

Hasil belajar siswa pada penelitian ini ditentukan melalui nilai tes yang diberikan pada setiap akhir pertemuan. Keberhasilan penerapan model pembelajaran Talking Chips terhadap peningkatan hasil belajar diukur dari ketuntasan belajar siswa. Pada penelitian ini, peneliti menerapkan kriteria ketuntasan minimal (KKM) sebesar 75. Hal ini berarti siswa dinyatakan tuntas apabila memperoleh nilai $\geq 75$.

Berdasarkan hasil evaluasi belajar pada siklus I diketahui bahwa tingkat penguasaan siswa terhadap materi ikatan kimia hanya 68\% siswa yang mencapai kriteria ketuntasan minimal (KKM), sehingga tindakan pada siklus I dapat dikatakan belum berhasil. Dimana dari 31 siswa hanya 19 siswa yang memperoleh nilai $\geq 75$. Dari hasil pengamatan,19siswayangmampumelebihikrit eriaketuntasanadalah siswa yang begitu antusias dan serius mengikuti pembelajaran dan mereka terlihat paling dominan dalam kelompoknya serta menjadi tempat bergantungteman-temannya.

Berdasarkan data hasil belajar pada siklus I dan siklus II, terjadi peningkatan pemahaman siswa terhadap materi ikatan kimia, hal ini ditandai dengan adanya peningkatan hasil belajar siswa pada siklus I sebesar 68\% menjadi 97\% di siklus II. Kegiatan siklus II ini dikatakan sudah berhasil karena lebih dari $75 \%$ siswa sudah menguasai materi dan mengalami peningkatan sebesar 29\% dibandingkan 
dengan siklus I. Hal ini dapat diamati pada Gambar 4.

Adanya peningkatan hasil belajar dari siklus I dan siklus II dikarenakan setiap kelompok sudah berhasil menyusun power point sehingga hampir seluruh siswa memahami materi, pemahaman siswa pada tahapan kegiatan pembelajaran sudah maksimal, siswa semakin bersemangat dan antusias dalam belajar. Tanpa pengarahan dari guru, siswa sudah mengalami perubahan pada tahapan - tahapan pembelajaran sesuai dengan pembagian waktu yang ada. Hal ini sesuai dengan pendapat ahli yang mengatakan bahwa belajar adalah suatu proses yang ditandai dengan adanya perubahan pada diri seseorang [19]. Perubahan dalam diri seseorang dapat ditunjukkan dalam berbagai bentuk seperti berubah pengetahuannya, pemahamannya, sikap dan tingkah lakunya, keterampilan dan kemampuannya, daya reaksinya, daya penerimaannya dan lain-lain aspek yang ada pada individu.

Perubahan hasil belajar siswa pada penelitian ini bersesuaian dengan penelitian lain, di antaranya penelitian $[20,21,22,23$, $24,25]$. Sesungguhnya peneliti lain yang meneliti pengaruh model pembelajaran Talking Chips sama dengan konten, lokasi, serta subjek yang berbeda namun menemukan hasil yang bersesuaian (yaitu adanya perubahan hasil belajar siswa menjadi meningkat) masih banyak. Hal ini menandakan bahwa model pembelajaran Talking Chips benar-benar reliable.

\section{Refleksi}

Hasil refleksi pada siklus I yang harus diperbaiki pada siklus II, yaitu: waktu pembelajaran pada siklus I masih belum efektif dan efisien, sehingga pada siklus II waktu pembelajaran harus diatur sebaik mungkin, siswa sulit beradaptasi dengan ruang belajar yang tidak biasa sehinggapembelajaransebaiknyadilakukandir uangkelasbiasa.Siswa masih kurang antusias dalam menyelesaikan tugas kelompok secara tepat waktu sehingga perlu dimotivasi karena kurang antusiasnya siswa dalam menyelesaikan tugas kelompok dalam hal ini menyusun power point berpengaruh pada kurangnya pemahaman siswa terhadap materi ikataniondanikatankovalen, siswaharuslebihse ringdimotivasiuntuk menggunakan kartunya (Talking Chips) ketika ingin bertanya, menjawab atau mengeluarkan pendapat sehingga semua siswa memiliki kesempatan yang sama untuk aktif.

Guru harus mampu melibatkan siswa dalam kegiatan pembelajaran secara optimal. Keaktifan siswa dalam proses pembelajaran menyebabkan interaksi yang tinggi antara guru dengan siswa ataupun dengan siswa itu sendiri. Hal ini mengakibatkan suasana kelas menjadi segar dan kondusif, dimana masing -masing siswa dapat melibatkan kemampuannya semaksimal mungkin. Aktivitas yang timbul dari siswa akan mengakibatkan pula terbentuknya pengetahuan dan keterampilan yang akan mengarah pada peningkatan prestasi.

Hal senada disampaikan bahwa pembelajaran yang efektif adalah pembelajaran yang menyediakan kesempatan kepada siswa untuk dapat belajar sendiri atau melakukan aktivitas sendiri [5]. Dalam aktivitas yang dilakukan oleh siswa dalam pembelajaran, mereka belajar sambil bekerja. Dengan bekerja tersebut, siswa mendapatkan pengetahuan, pemahaman, dan aspek-aspek tingkah laku lainnya.

Berdasarkan paparan tersebut dapat diketahui bahwa model Talking Chips dapat meningkatkan aktivitas belajar siswa di kelas $\mathrm{X}$ MIA 2 MAN 13 Jakarta. Siswa yang memiliki aktivitas belajar yang tinggi akan berperan aktif dalam pembelajaran, hal ini berimbas pada hasil belajar yang maksimal. Hasil penelitian ini sesuai dengan pernyataan bahwa meningkatnya partisipasi siswa maka hasil belajar siswa juga akan ikut meningkat [17, 24]. Jadi, partisipasi siswa sangat penting dalam meningkatkan prestasi siswa.

\section{SIMPULAN DAN SARAN}

\section{Simpulan}

Berdasarkan hasil penelitian terhadap siswa kelas X MIA 2 MAN 13 Jakarta tahun pelajaran 2017 - 2018, dapat disimpulkan bahwa pembelajaran ikatan kimia dengan model pembelajaran Talking Chips dapat meningkatkan hasil belajar siswa ditinjau dari 
aspek kognitif dimana taraf penguasaan siswa melebihi $75 \%$ materi yang diajarkan, dengan rata-rata hasil belajar siswa meningkat dari siklus I sebesar $68 \%$ menjadi $97 \%$ pada siklus II dengan peningkatan sebesar $29 \%$. Begitu pula dengan aktivitas belajar siswa, meningkat dari siklus I sebesar $61 \%$ menjadi $85 \%$ pada siklus II dengan peningkatan sebesar $24 \%$.

\section{Saran}

Adapun saran yang dapat peneliti kemukakan sehubungan dengan hasil penelitian yang diperoleh adalah: (1) Bagi guru yang ingin menggunakan model pembelajaran Talking Chips perlu memberikan penjelasan dengan rinci mengenai tahapan pelaksanaan pembelajaran agar pembelajaran dapat berjalan sesuai dengan waktu yang ditentukan, (2) Perlu adanya penelitian lanjutan tentang penggunaan model pembelajaran Talking Chips yang dikombinasikan dengan model atau pendekatan pembelajaran lain dengan memperhatikan karakterisktik materi yang diajarkan.

\section{UCAPAN TERMAKASIH}

Terima kasih diucapkan peneliti kepada Kepala MAN 13 Jakarta, teman-teman guru, serta siswa-siswi sekalian yang telah mendukung hingga PTK ini dapat diselesaikan dengan baik oleh peneliti.

\section{DAFTAR PUSTAKA}

[1] Rosyada, D. (2016). Antara Pendidikan dan Pembelajaran. Diperoleh tanggal 16 Agustus 2018, dari http://www.uinjkt.ac.id/id/antarapendidikan-dan-pembelajaran/.

[2] Undang-Undang No. 20 Tahun 2003 tentang Sistem Pendidikan Nasional.. (2003, 8 Juli). Ketentuan Umum. Diperoleh tanggal 16 Agustus 2018, dari http://referensi.elsam.or.id/2014/11/uunomor-20-tahun-2003-tentang-sistempendidikan-nasional/.

[3] Undang-Undang No. 12 Tahun 2012 tentang Sistem Pendidikan Nasional. (2012, 10 Agustus). Ketentuan Umum. Diperoleh tanggal 16 Agustus 2018, dari http://referensi.elsam.or.id/2014/11/uu- nomor-20-tahun-2003-tentang-sistempendidikan-nasional/.

[4] Definisi Belajar, Pembelajaran, Pendidikan, Pengajaran. (2013, 29 November). Diperoleh tanggal 16 Agustus 2018, dari https://jombangpustaka.wordpress.com/2 013/11/29/definisi-belajar-pembelajaranpendidikan-pengajaran/.

[5] Hamalik, O. (2011). Proses Belajar Mengajar. Jakarta: Bumi Aksara.

[6] Danim, S. (2010). Pengantar Kependidikan. Bandung: Alfabeta.

[7] Permendikbud No. 65 Tahun 2013 tentang Standar Proses Pendidikan Dasar dan Menengah. Pendahuluan. Diperoleh tanggal 16 Agustus 2018 dari https://luk.staff.ugm.ac.id/atur/bsnp/Perm endikbud65-2013SI.pdf.

[8] Peraturan Pemerintah No. 19 Tahun 2005 tentang Standar Nasional Pendidikan. Standar Proses. Diperoleh tanggal 16 Agustus 2018 dari http://pelayanan.jakarta.go.id/download/r egulasi/peraturan-pemerintah-nomor-19tahun-2005-tentang-standar-pendidikannasional.pdf.

[9] Riyanto, Y. (2009). Paradigma Baru Pembelajaran (Sebagai Referensi bagi Pendidik dalam Implementasi Pembelajaran yang Efektif dan Berkualitas. Jakarta: Kencana Prenada Media Group.

[10] Syahriani. (2017). Peningkatan Aktivitas Dan Hasil Belajar Biologi Melalui Pembelajaran Kooperatif Tipe Team Assisted Individualization. Jurnal Biotek, 5 (1), 69-86. Diperoleh tanggal 16 Agustus 2018 dari journal.uinalauddin.ac.id/index.php/biotek/article/vie w/3447.

[11] Winarti, Masriani, \& Hadi. (2017). Pengaruh Model Role Playing terhadap Minat dan Hasil Belajar Siswa pada Materi Ikatan Kimia. Jurnal Pendidikan dan Pembelajaran, 6(9), 17521-17530. Diperoleh tanggal 16 Agustus 2018 dari http://jurnal.untan.ac.id/index.php/jpdpb/a rticle/view/21681/17530. 
[12] Isjoni. (2016). Cooperative Learning. (Cetakan ke-8). Bandung: Alfabeta.

[13] Mulyatiningsih, E. (2013). Metode Penelitian Terapan Bidang Pendidikan. (Cetakan Pertama). Bandung: Alfabeta.

[14] Taniredja, Tukiran, Irma Pujianti, dan Nyata. (2011). Penelitian Tindakan Kelas. Bandung: Alfabeta.

[15] Arikunto, Suharsimi. (2010). Prosedur Penelitian Suatu Pendekatan Praktik. Jakarta: Raja Grafindo Persada.

[16] Anas, S. (2011). Pengantar Evaluasi Pendidikan. Jakarta:Rajawali Press.

[17] Khodijah, D. N., Hendri, M., Darmaji. (2016). Upaya Meningkatkan Partisipasi dan Hasil Belajar dengan Menggunakan Model Pembelajaran Kooperatif Tipe Think Pair Share di Kelas Xi Mia7 Sman 1 Muaro Jambi. Jurnal EduFisika. 1(2), 46-54. Diperoleh tanggal 16 Agustus 2018 dari https://onlinejournal.unja.ac.id/index.php/EDP/issue/vi ew/537

[18] Slameto. (2010). Belajar dan Faktorfaktor Yang Mempengaruhinya. Jakarta. PT. Rineka Cipta.

[19] Sutrisno \& Siswanto. (2016). FaktorFaktor yang Mempengaruhi Hasil Belajar Siswa pada Pembelajaran Praktik Kelistrikan Otomotif SMK di Kota Yogyakarta. Jurnal Pendidikan Vokasi, 6(1), 111-120. Diperoleh tanggal 16 Agustus 2018 dari http://journal.uny.ac.id/index.php/jpv.
[20] Hamida. (2017). Pengaruh Model Pembelajaran Talking Chips dengan Metode Pembelajaran Mind Mapping terhadap Retensi dan Hasil Belajar Biologi Siswa. Jember: Digital Repository Universitas Jember.

[21] Nurlaela, S. (2017). Perbandingan Life Skills yang Menggunakan Model PembelajaranKooperatif Tipe Talking Chips, Tipe Class Wide Peer TutoringDan Tipe Group Resume pada Mata PelajaranIPS Siswa Kelas VII SMP Negeri 1 PesawaranTahun Pelajaran 2016/2017. Lampung: FKIP Universitas Lampung.

[22] Rahmawati, L., Jatmiko, B., Raharjo. (2016). Pengembangan Perangkat Pembelajara Ipa Menggunakan Model Kooperatif Tipe Stad Dengan Strategi Talking Chips Untuk Meningkatkan Hasil Belajar. Pendidikan Sains Pascasarjana Universitas Negeri Surabaya, 5(2), 968974.

[23] Sari, G., Abdullah, R., Badlisyah, T. (2017). Penerapan Model Pembelajaran Talking Chips dalam Meningkatkan Hasil Belajar Siswa pada Materi Asam Basa di Sman 1 Meureubo Aceh Barat. Prosiding Seminar Nasional MIPA III, hal. 161-167.

[24] Undang-Undang No. 20 Tahun 2003 tentang Sistem Pendidikan Nasional.. (2003, 8 Juli). Ketentuan Umum. Diperoleh tanggal 16 Agustus 2018, dari http://referensi.elsam.or.id/2014/11/uunomor-20-tahun-2003-tentang-sistempendidikan-nasional/ 